Dr VLADIMIR PETROVIĆ, naučni savetnik

Institut za savremenu istoriju

Beograd, Republika Srbija

UDK 94(497.1)"1993"

vladimir.petrovic@isi.co.rs

341.37(497.1)"1993"

355.426(497.6)"1991/1995"

originalan naučni rad / original scientific paper

primljeno / received: 25. 1. 2021.

prihvaćeno / accepted: 19. 5. 2021.

https://doi.org/10.29362/ist20veka.2021.2.pet.435-460

\title{
NEUSPEH ŽENEVSKIH PREGOVORA O PREKIDU RATA U BOSNI I HERCEGOVINI JANUARA 1993.
}

APSTRAKT: Članak rekonstruiše $i$ analizira početnu etapu mirovnih pregovora o Bosni i Hercegovini, vođenih u Ženevi u januaru 1993. godine. Tu je stranama u konfliktu prezentovan prvi kompletan mirovni nacrt koji su izradili kopredsedavajući Međunarodne konferencije o bivšoj Jugoslaviji, Sajrus Vens i Dejvid Oven. Usledio je mučni jednomesečni pregovarački period, rekonstruisan ovde na osnovu dostupne arhivske građe, sudskih spisa, objavljenih dokumenata i memoara učesnika. Analizom deklarativnih pozicija strana u sukobu, interakcija između njihovih delegacija i odnosa unutar njih, zapaža se da su sve strane vodile dvostruku igru. Dok je na hrvatskoj strani prividno postojala spremnost da se plan prihvati, ona ga je opstruisala eskalacijama na terenu. Dok je Beograd savetovao prihvatanje plana, Pale se o te savete oglušivalo, takođe produbljujući sukobe. Sarajevo je odlagalo prihvatanje plana, nadajući se direktnijoj američkoj intervenciji. Takva mogućnost je i nagoveštena nakon januarske inauguracije administracije Bila Klintona, potkopavajući položaj međunarodnih posrednika. Mirovno rešenje je bilo neprihvatljivo glavnim pregovaračima, jer je odstupalo od maksimalističkih ciljeva koje su zacrtali i propagirali. Prihvatanje takvog kompromisa se ne samo kosilo sa njihovom opštom ratnom strategijom, već je ugrožavalo i njihov opstanak na vlasti.

KLJUČNE REČI: Rat u Bosni i Hercegovini, Međunarodna konferencija o bivšoj Jugoslaviji, Slobodan Milošević, Radovan Karadžić, Franjo Tuđman, Alija Izetbegović, Vens-Ovenov mirovni plan

Tokom prerastanja jugoslovenskog raspada u rat, međunarodna zajednica je eksperimentisala sa različitim instrumentima za rešavanje te krize. Od šatldiplomatije evropske ministarske Trojke, preko Arbitražne komisije nazvane po Roberu Badenteru, do stvaranja stalne Konferencije Evropske zajednice o Jugoslaviji kojom je predsedavao lord Piter Karington, ovi mehanizmi nisu dali većih rezultata. ${ }^{1}$ Rasplamsavanjem rata u Bosni pojavila se potreba za širim okvi-

\footnotetext{
${ }^{1}$ Kosta Nikolić, „Srbija i plan lorda Karingtona na Mirovnoj konferenciji u Hagu 1991“, u: Jugoslavija između ujedinjenja i razlaza, Hrvatsko-srpski odnosi u kontekstu društvenog razvoja dve
} 
rom, koji je postavljen avgusta 1992. otvaranjem Međunarodne konferenciji o bivšoj Jugoslaviji u Londonu u prisustvu najviših državnika sveta. Konferencija je zatim postala stalna. Preseljena je u Ženevu, pod kopredsedavanjem britanskog lorda Dejvida Ovena ispred Evropske unije i bivšeg američkog državnog sekretara Sajrusa Vensa ispred Ujedinjenih nacija. ${ }^{2}$

Vens i Oven su do kraja godine izradili prvi sveobuhvatan i konkretan predlog sporazuma za obustavu rata u Bosni i Hercegovini. Na njemu je radila i grupa saradnika među kojima su najvažniju ulogu imali Marti Ahtisari i Herbert Okun, ${ }^{3}$ uz konsultovanje sa relevantnim međunarodnim faktorima. ${ }^{4}$ Njihovim posredovanjem su početkom 1993. u Ženevi prvi put od izbijanja rata za pregovarački sto seli gotovo svi njegovi protagonisti, kako Alija Izetbegović, Radovan Karadžić i Mate Boban, tako i Franjo Tuđman i Dobrica Ćosić, tako i Ratko Mladić, Sefer Halilović i Milivoj Petković. „Pre nego što sam otišao u Ženevu, 1. januara 1993, premijer Džon Mejdžor me je posle ručka u letnjoj rezidenciji u Čekersu upitao kakve su šanse da se postigne sporazum. Odgovorio sam: polapola“, sećao se lord Oven. Dan kasnije, Oven je otvorio pregovore u prisustvu protagonista: „Sedeli su za istim stolom prvi put od Londonske konferencije u avgustu i koristili su uvodnu sesiju da se izduvaju. Sajrus Vens je objasnio da će se rad nastaviti u dve grupe: jednom će predsedavati Marti Ahtisari, koja će se baviti ustavnim pitanjima, uključujući i predložene mape administrativnih granica unutar Bosne i Hercegovine, a druga, kojom će predsedavati komandant UNPROFOR-a, general Nambijar, biće posvećena vojnim pitanjima“" 5

Pregovori su otvoreni izlaganjem nacrta mirovnog plana, koji je u vojnom pogledu predviđao obustavu sukoba, dok je suština političkog rešenja predstavljala kompromis - održanje međunarodnog subjektiviteta Bosne i Hercegovine, uz njenu decentralizaciju na 10 de facto etnički razgraničenih, ali prostorno teritorijalno nepovezanih provincija. Narednih nedelja predstavnici bosanske, srpske i hrvatske strane razmatrali su aspekte ovog plana kako u Ženevi, tako i u Beogradu, Zagrebu, Sarajevu, Mostaru i Palama, nastojeći da ga

Jugoslavije 1918-1991, uredili Bojan Dimitrijević i Mario Jareb (Beograd: Institut za savremenu istoriju, 2018), 225-260. O diplomatskim neuspesima u ranoj fazi sukoba piše Josip Glaurdić, The Hour of Europe. Western Powers and the breakup of Yugoslavia (New Heaven: Yale University Press, 2011), 173-249.

${ }^{2}$ O Londonskoj konferenciji videti u: Vladimir Petrović (prir.), Srpske političke elite i Londonska konferencija. I-II (Beograd: Institut za savremenu istoriju, 2014, 2016); James Gow, Triumph of the Lack of Will. International Diplomacy and the Yugoslav War (London: Hurst\&co, 1997), 90-98.

${ }^{3}$ Martti Ahtisaari (1937), finski diplomata i zvaničnik Ujedinjenih nacija aktivno angažovan u mirovnom procesu u bivšoj Jugoslaviji. Bio je predsednik Finske od 1994. do 2000, kada se uključio u rešavanje ratne i postratne situacije na Kosovu i Metohiji. Herbert Stuart Okun (1930-2011), američki karijerni diplomata. Tokom Hladnog rata službovao u Sovjetskom Savezu, a bio je i Nemačkoj Demokratskoj Republici (DDR). Od 1991. do 1997. bio je Vensov specijalni savetnik.

${ }^{4}$ Dokumenta vezana za nastanak plana objavljena su u: Bosnia-Herzegovina: The Vance/Owen Peace Plan, ed. David Owen (Liverpool: Liverpool University Press, 2013), 13-71. Zvanična dokumenta o pregovaračkom procesu objavljena su na gotovo 2000. strana u: The International Conference on the Former Yugoslavia: Official Papers, priredio Bertrand Ramcharan (Hague: Boston: Kluwer Law International, 1997), I, 249-265.

${ }^{5}$ David Owen, Balkan Odyssey (London: Indigo, 1996) 93-94. 
usklade kako sa svojim ratnim ciljevima, tako i sa političkim ambicijama. Pregovori su poprimili karakter drame koja se odvijala u nekoliko činova.

\section{Prvi čin: Prezentacija Vens-Ovenovog plana u Ženevi (2-4. januar 1993)}

U prvoj fazi rada ženevske konferencije prezentovana su dva dokumenta, Sporazum koji se odnosi na Bosnu i Hercegovinu i Sporazum o miru u Bosni $i$ Hercegovini. Delegacijama koje su predvodili Alija Izetbegović, Radovan Karadžić i Mate Boban predstavljen je politički sporazum, u kojem su skicirani principi za budući ustavni okvir države. Mapirana je podela na oblasti, definisan odnos između provincija i centralnih vlasti i usaglašena saradnja u humanitarnim naporima. Sadržaj drugog dokumenta, koji se odnosio na implementaciju primirja, linije razgraničenja i dinamiku postepenog razvojačenja, predstavio je komandant UNPROFOR-a, indijski general Satiš Nambijar, a trebalo je da ga potpišu komandanti suprotstavljenih vojski, Ratko Mladić, Sefer Halilović i Milivoj Petković. Okupljeni su sa nekim od ovih vojno-političkih rešenja bili upoznati u ranijim verzijama, ali je definitivan izgled mapa predstavljao ključnu novinu, pošto su Oven i Ahtisari na njima radili do samog otvaranja skupa, ali u strogoj tajnosti. ${ }^{6}$ „Pazili smo da ne označimo provincije kao srpske, hrvatske i muslimanske, iako su pojedine novine i komentatori stekli takav utisak. Stavljali smo samo brojeve i imena mesta na mape“. ${ }^{7}$ Svakome je, međutim, bilo jasno da će provincije po pravilu imati jasnu etničku dominaciju.

Kako su utihnuli pozdravni govori puni deklarativne podrške mirovnom procesu, nakon što su mape stavljene na sto, pokazalo se da, sem na hrvatskoj strani, nije postojala spremnost da se dokumenta u postojećem obliku potpišu. ${ }^{8}$ Dobrica Ćosić se sećao: „Bili su to dosad najteži pregovori u Ženevi. Nepremostive suprotnosti među zaraćenim stranama i svima nama koji u tim pregovorima učestvujemo. Vens i Oven, kao predstavnici Ujedinjenih nacija i Evropske zajednice, sigurno po nalogu velikih sila, organizovali su do sada najambicioznije pregovore o ratu i miru u Bosni i Hercegovini, zahtevajući da, pored predstavnika zaraćenih strana i vojnih komandi, učestvujemo Tuđman i ja. Oni su doneli svoj plan ustavnog uređenja poratne $\mathrm{BiH}^{*} .9$

Srpska strana je oba sporazuma prihvatila, ali samo u načelu i kao osnovu za dalje pregovore, suprotstavljajući se formulacijama ustavnih principa. Bosanska strana je naprotiv prihvatila ustavne principe, a načelno i sporazum o miru, ali je iskazala rezerve prema predviđenom odnosu između provincija i

\footnotetext{
6 "Memo from Lord Owen to Martti Ahtisaari on adjustments to maps" (31 December 1992), u: D. Owen Bosnia-Herzegovina: 198-199. Nacrt mirovnog plana predložen 2. januara 1993. u: Vladimir Petrović (prir.), Srpske političke elite $i$ Vens-Ovenov plan I (Beograd: Institut za savremenu istoriju, 2010), 11-17.

${ }^{7}$ D. Owen, Balkan Odyssey, 93.

${ }^{8}$ Govori na otvaranju plenarne sesije u: D. Owen, Bosnia-Herzegovina:, 206-208. Videti i University of Liverpool Library, David Owen's Papers, Supplementary Documents (Lord Owen's Papers), 6674 https://libguides.liverpool.ac.uk/ld.php?content_id=31121178 (pristupljeno 24. 1. 2021).

${ }^{9}$ Dobrica Ćosić, Piščevi zapisi 1992-1993 (Beograd: Filip Višnjić, 2004), 230.
} 
centralnih vlasti. Predsednici SRJ i Hrvatske, Ćosić i Tuđman, zalagali su se za pronalaženje sveobuhvatnog rešenja, sa tim što je prvi tvrdio da Savezna Republika Jugoslavija nema pretenzija na Bosnu, a drugi da je Hrvatska prava žrtva jugoslovenske agresije. ${ }^{10}$ Razilaženja su bila još veća istog popodneva u radnim grupama, posebno na onoj koja je razmatrala predložene mape provincija. Mate Boban je rekao da smatra da su mape manje-više objektivne, ali ni Izetbegović ni Karadžić nisu krili svoje nezadovoljstvo. Izetbegović je bio iznenađen odredbom o specijalnom statusu Sarajeva i imao je niz primedbi na razgraničenja među provincijama, dok je Karadžić zapazio da se od srpske strane očekuje povlačenje sa značajnog dela teritorije. Dok su njegovi saradnici računali procente, golim okom je bilo jasno da se od srpske strane koja je u tom trenutku kontrolisala nešto više od dve trećine Bosne i Hercegovine očekuje da se ograniči na nešto manje od polovine svoje teritorije, pri tome podeljene u tri teritorijalno razdvojene provincije. ${ }^{11}$

Izetbegović je dalje ,smatrao da je prva provincija (Bihać) neprihvatljiva jer se njome priznaju rezultati etničkog čišćenja. Ključ, koji je pre rata bio 50\% srpski i 48\% muslimanski, bi trebao da bude u bihaćkoj provinciji. Drugo, Izetbegović je kritikovao konfiguraciju provincije 5, tvrdeći da je neprirodna. Umesto nje je predlagao formiranje dve provincije - prvu oko Tuzle i drugu oko Goražda. Dalje je smatrao da tuzlanska provincija treba da ima pristup reci Savi kod Brčkog, koje je opisao kao muslimanski grad pre rata. Treće, Izetbegović je smatrao da opštine Čajniče i Rudo treba uključiti u muslimansku provinciju. U zaključku je rekao da će docnije izneti svoje komentare vezane za Sarajevo“. Karadžić je takođe ponudio niz izmena: „Prvo, što se tiče provincije 1, tvrdio je da logična linija podele ide dolinom reke Une, pošto prema njemu Muslimani žive na njenoj zapadnoj obali, a Srbi na istočnoj. Pokazao je određenu fleksibilnost oko opštine Sanski Most, stavljajući u izgled neku vrstu aranžmana sličnog Šekovićima u provinciji 6. Izjavio je da će sa Hrvatima prodiskutovati situaciju koja se tiče Kupresa i Glamoča u provinciji 10. Takođe je rekao da je provincija 5 neprihvatljiva. Složio se sa predsednikom Izetbegovićem da je treba podeliti u dve oblasti. Prva bi išla zapadno od opština Kalesija i Kladanj. Druga bi uključivala Čajniče, Rudo i delove Goražda i Foče. Pri kraju je rekao da će morati biti nekih pregovora oko provincije 3 (Posavina) koju je smatrao ključnom za bosanske Srbe“. ${ }^{12}$ Posavina i Podrinje, dakle, pokazali su se kao najspornije tačke.

Ne samo što delegacije nisu približile stavove, već se na radnim grupama pokrenuo niz spornih pitanja koja su proizilazila iz vojnog dokumenta, a ticala su se dinamike povlačenja trupa, stvaranja novih linija razgraničenja, kontrole teškog naoružanja i drugih prelaznih aranžmana. U takvoj atmosferi

10 "Record of First Plenary meeting of ICFY Peace Talks", 2. 1.1993, u: D. Owen, BosniaHerzegovina, 206-207.

11 "ICFY Memo from Peter Beshar to Co-Chairmen on afternoon session of Working Group", 2. 1. 1993, u: D. Owen, Bosnia-Herzegovina, 209-210. Srpska strana je u tom trenutku kontrolisala gotovo $70 \%$ teritorije $\mathrm{BiH}$, a po predloženoj mapi taj procenat bi se smanjio na $45 \%$, odnosno za jednu trećinu.

${ }^{12}$ Isto, 209-210. 
nepoverenja, Vens i Oven su zakazali novu plenarnu sednicu 4. januara na kojoj su insistirali da se okupljeni opredele spram predloga, podsetivši ih da je ,izbor između rata i mira njihov.“13 Shodno tome, „na zatvaranju sastanka bosanski Hrvati su prihvatili naš trodelni paket u celosti. Karadžić je rekao da je za bosanske Srbe mapa 'prihvatljiva kao osnova za otvaranje pregovora'. Odbio je prvi i drugi ustavni princip, koji su sprečavali stvaranje države u državi i ostavio otvorenim mogućnost pregovora o prekidu neprijateljstava. Bilo je očigledno da bosanski Srbi nikada neće prihvatiti mape ako ne budu sasvim izolovani“, sećao se Oven. Radi toga je predložio Ćosiću da uključi Miloševića u delegaciju: „Mislili smo da će posle izbornih rezultata Milošević biti spremniji da pritisne Karadžića, a i efikasniji u tome nego Ćosić, što se docnije i pokazalo““. ${ }^{14}$ Uvidevši da na licu mesta ne postoji spremnost da se mirovni sporazum potpiše u paketu, kopredsedavajući su predložili pauzu tokom pravoslavnih božićnih praznika i zakazali novu rundu pregovora za 10. januar.

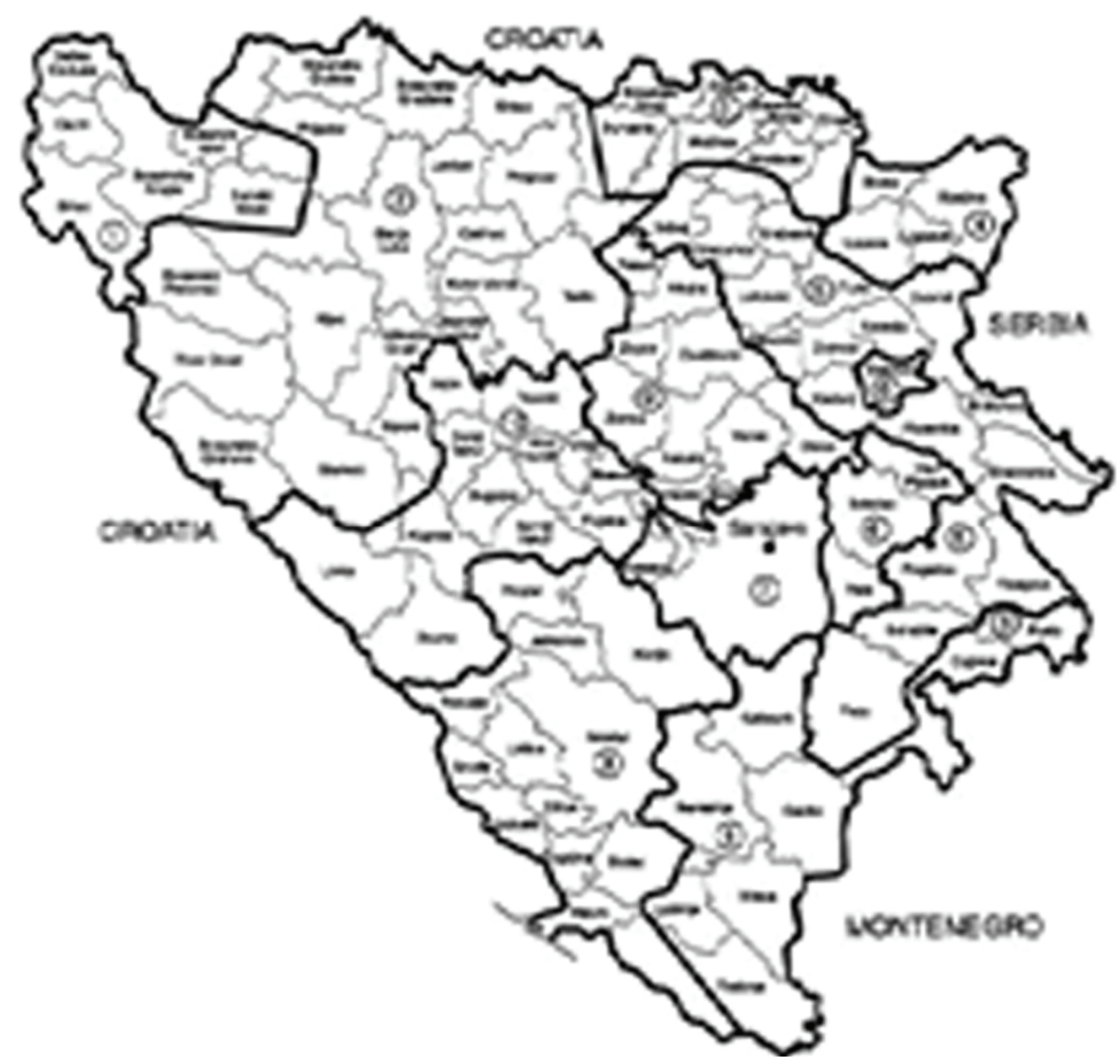

Mapa provincija predložena u januaru 1993.

13 “The Pentagonal Peace Talks: 2-4 January 1993", Lord Owen's Papers, p. 80.

${ }^{14}$ D. Owen, Balkan Odyssey, 93. 


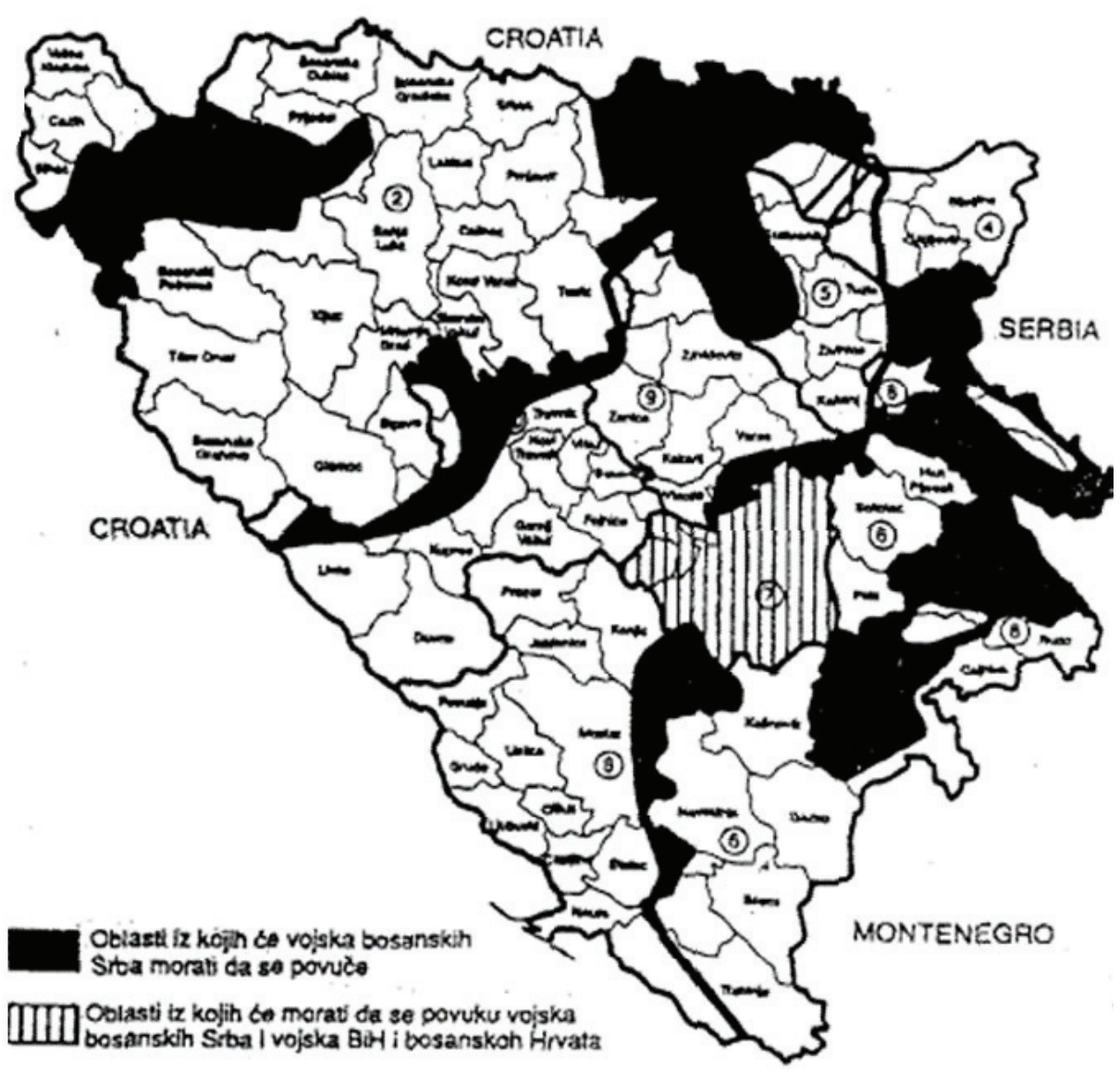

Predviđeno povlačenje srpske strane (crno)

\section{Kratak intermeco: Bijeljina i Beograd (5-9. januar 1993)}

„Šta da činimo?“, pitao se Dobrica Ćosić, koji je veoma ozbiljno shvatio Ovenove pretnje: „Imam utisak da će Srbija i Crna Gora platiti ceh bosanskih Srba u ovom ratu. Veoma sam zabrinut za našu budućnost. Odlučio sam da se sutra, na Badnje veče, obratim građanima Srbije i Crne Gore i izvestim ih o razgovoru u Ženevi i položaju u kome se našla naša zemlja. Tim govorom pokušaću da zadobijem podršku naroda za svoju politiku istorijskog kompromisa“. ${ }^{15}$ U tom televizijskom obraćanju je rekao: „Nama se danas sudi bez našeg prisustva; nama se izriču presude bez prava na žalbu; nama se saopštavaju na lažima zasnovani ultimatumi za nacionalnu i državnu kapitulaciju, a za neprihvatanje bivamo stavljeni u koncentracioni logor i preti nam se napadom najjačih armija sveta. [...] Sam opstanak nas primorava da prihvatimo zakone,

${ }^{15}$ D. Ćosić, Piščevi zapisi 1992-1993, 231. 
zahteve i naloge sveta i civilizacije u kojoj još postojimo. Prilagođavanje je prvi egzistencijalni postulat srpskog naroda danas. Valjda nas je istorija urazumila da uvažavamo realnost sveta $\mathrm{i}$ da učimo od boljih $\mathrm{i}$ naprednijih. Neophodnost prilagođavanja treba da bude filozofija našeg razvoja. Ako se u tome ne saglasimo i tako ne postupamo, ostaćemo narod parija i bede“. ${ }^{16}$

Naredni dani, međutim, nisu doneli smirivanje, već rasplamsavanje nasilja. Tokom 7. i 8. januara trupe Armije BiH iz Srebrenice napale su i opljačkale Kravicu i okolna sela, ubivši najmanje 43 vojnika i civila. ${ }^{17}$ U Sarajevu je 8 . januara jedan vojnik Vojske Republike Srpske (VRS) izrešetao Hakiju Turajlića, potpredsednika vlade $\mathrm{BiH}$, iako se nalazio u vozilu Ujedinjenih nacija, naočigled vojnika UNPROFOR-a i na užas kopredsedavajućih mirovne konferencije, koji su ovo ubistvo oštro osudili i zahtevali od Karadžića i Mladića da se odgovorni procesuiraju. ${ }^{18}$ Oni su međutim bili zauzeti sasvim drugim poslom - učvršćivanjem sopstvenih pozicija kroz predočavanje svog ženevskog angažmana poslanicima Narodne skupštine Republike Srpske koja je zasedala u Bijeljini 8. januara. Tamo su se poslanici utrkivali u tome ko će rečitije formulisati njihovu jedinstvenu poruku - ne dati ni pedlja teritorije. Sednicom je odjekivala takva retorika da je sam Mladić upozoravao da ,ne moramo mnogo vatreno i preteći da istupamo. [...] Ne znam kako ćemo se mi pojaviti gore na ovim pregovorima u Ženevi, radi ovakvih situacija“, rekao je, opisavši poslanicima ubistvo Turajlića. Međutim, poslanici su informaciju o ovoj pogibiji propratili aplauzom, a delegaciju su obavezali da na nastavku pregovora ne ide ispod zacrtanog praga. ${ }^{19}$ Izetbegović je tvrdio da ne postoje uslovi za njegov povratak u Ženevu, pa je u takvim okolnostima bilo pitanje čak i da li će se predstavnici zaraćenih strana pojaviti na drugoj rundi ženevskih pregovora, a kamoli sa kakvim stavovima.

${ }^{16}$ Dobrica Ćosić, „Perpetualna kriza Balkana“, Novosti, 21. 3. 2003. https://www.novosti.rs/ dodatni_sadrzaj/clanci.119.html:276089-perpetualna-kriza-balkana (pristupljeno 24. 1. 2021).

${ }^{17}$ Prema podacima Generalštaba Armije BiH od 29. maja 1997. napad na Kravicu vodio je Šemsudin Salihović (mašinbravar pre rata, a posle rata je imao čin kapetana), pripadnik Ceranskog odreda. Napad je planirao Ferid Hodžić, u tom trenutku komandant Štaba TO Vlasenica („Ujedinjene nacije. Sudski spisi Međunarodnog krivičnog tribunala za bivšu Jugoslaviju“ (United Nations ICTY Court Records), http://icr.icty.org. [dalje: Tribunal], Predmet: IT-03-68: Naser Orić, dokaz P88).

${ }^{18}$ D. Owen, Bosnia-Herzegovina, 223.

${ }_{19}$ Tribunal: Predmet IT-95-5/18: Radovan Karadžić i Ratko Mladić, dokazi P01422 i P03059. Zapisnik sa 24. sednice Narodne skupštine Republike Srpske održane u Bijeljini 8. januara 1993. godine. - Na ovoj sednici general Mladić je govorio i o ubistvu Hakije Turajlića: „Iz Sarajeva u vozilu UNPROFOR-a u kojem je bio pukovnik Sartr, Francuz, bio je i potpredsjednik Turajlić Hakija, te krnje vlade Bosne i Hercegovine, naši su to vozilo zaustavili i pretresli, jedan od naših vojnika je sa šest metaka ubio tog Turajlića. (Aplauz). Molim vas da ne razbijamo tako klimu prema UNPROFOR-u, ima i onih koji dobro rade. Mi ćemo uložiti oštar protest, ja sam naredio već da napišu protest do Nambiara, i ja sam to njima rekao prošli put, UNPROFOR niti Ujedinjenje Nacije nisu servis ni logistika Alije Izetbegovića niti Franje Tuđmana niti naš, ali ipak moramo voditi račun, moramo biti mnogo, mnogo trezne glave. Ja vas molim da nemojmo da nas neki pojedinac povuče u nesreću“. Bitni izvodi iz rasprava u Skupštini Republike Srpske relevantni za optužnicu protiv Ratka Mladića, 1991-1996. Pripremio: Robert J. Donia, Centar za ruske i istočnoevropske studije, Univerzitet u Mičigenu, SAD, 18. februar 2013, 115; dostupno na: Tribunal: Karadžić, Mladić. Notice. 
O tome se raspravljalo u Beogradu 9. januara, gde je predsednik Savezne Republike Jugoslavije Dobrica Ćosić radi toga sazvao sednicu Saveta za usaglašavanje stavova o državnoj politici u proširenom sastavu. Tom sastanku je, pored članova ovog tela (Dobrica Ćosić, Slobodan Milošević, Momir Bulatović, Života Panić, Ilija Đukić, Radoje Kontić), prisustvovalo rukovodstvo Republike Srpske (Radovan Karadžić, Momčilo Krajišnik, Ratko Mladić, Nikola Koljević) i Republike Srpske Krajine. Rukovodstvo bosanskih Srba je bilo jednodušno u otporu planu, po cenu potpune konfrontacije sa međunarodnom zajednicom. Momčilo Krajišnik je istakao: „Konstatovali smo da je osnovna činjenica da ne možemo prihvatiti osnovni ultimativni zahtjev koji su Evropska zajednica i Ujedinjene nacije pred nas postavili, da priznamo Bosnu i Hercegovinu kao državu“. ${ }^{20}$ Radovan Karadžić je tvrdio: „Po našem dubokom uvjerenju, predlozi su tako napravljeni i sračunati da ih Srbi odbiju. Mapa je provokativno antisrpska, kao i ustavni principi. [...] Oni, dakle, ne žele silom da nas liše naših prava; oni traže našu kooperativnost na našem uništavanju. To je nama potpuno jasno i zato ne možemo da prihvatimo ništa što definiše do kraja našu sudbinu“. Kontra predlog je formulisao Nikola Koljević: „Odavno smo razmišljali o toj ideji - potrebi za sve srpskom skupštinom, skupštinom svih legitimnih predstavnika srpskog naroda u različitim delovima bivše Jugoslavije. Mislimo da bi to bio jako značajan i krupan korak, za razliku od onih sitnih koje smo do sada koristili, taktizirajući i pokušavajući da nadlukavimo mnogo lukavije od nas. To bi bio taj krupan korak - organizovanje jedne takve skupštine“". ${ }^{21}$

Predsednici SRJ, Srbije i Crne Gore, Dobrica Ćosić, Slobodan Milošević i Momir Bulatović bili su suprotnog mišljenja, uvereni da bi unilateralno odbacivanje plana dovelo do daljeg stezanja sankcija, a možda i do vojne intervencije. Posebno je Slobodan Milošević, zabrinut zbog štete koju je sunovrat ekonomije nanosio njegovoj vlasti, insistirao na nastavku pregovora, i nije se libio da kritikuje rukovodstvo Republike Srpske: „Ne bih bio za to da se sada ovde zaklinjemo u strateške ciljeve; oni su jasni. Ovde nema nikoga za stolom koji to mišljenje ne deli. Naš je strateški cilj da srpski narod na Balkanu bude slobodan i ravnopravan [...] Iako je plan koji je predložen, kao i tačke, za sada nepovoljan, treba raditi da se one preokrenu u povoljnu definiciju naših stvari; oni ipak sadrže glavnu povoljnu komponentu i glavno opredeljenje. Naime, već sam u sebi sadrži razgraničenja po etničkom principu, što su oni, do skoro, tvrdili da uopšte ne dolazi u obzir. [...] Prema tome, ja bih bio za jedan prilaz koji, u ovom trenutku, može maksimalno da ,omekšava" njihove ponuđene principe $\mathrm{i}$ da ih okreće. [...] Dakle, ja sam za pragmatičan pristup postojećim uslovima i okolnostima, međunarodnom okruženju i iskorišćavanju mogućnosti da se stvari vode dalje; pre nego za momentalnu konfrontaciju koja, praktično, iza sebe nema drugi korak ${ }^{6}{ }^{22}$

\footnotetext{
20 Tribunal: Predmet IT-02-54: Slobodan Milošević, dokaz P469.40. Stenografske beleške sa proširene sednice Saveta za usaglašavanje stavova o državnoj politici. Objavljeno u V. Petrović, Srpske političke elite i Vens-Ovenov plan I, 38.

${ }^{21}$ Isto, I, 41-42, 46.

${ }^{22}$ Isto, I, 62-65.
} 
Karadžić nije bio impresioniran ovim argumentom, ističući svoj doživljaj međunarodnih pregovarača: „Moram da vam kažem da su to pravi razbojnici; oni su kriminalci, potpuno amoralni, koji su spremni da prevare. [...] Vjerujte mi, bila bi katastrofa da mi ovo prihvatimo“. Nikola Koljević je umesto toga predložio „da budemo drugi, Alija samo da bude prvi koji neće da potpiše, mi smo opet dobili [...] nama će Alija svojim greškama pomoći“. Slobodan Milošević se sa time slagao: „Bilo bi najbolje Aliju dovesti na 'brisani prostor', da on bude taj". ${ }^{23}$ Međutim, kako je sednica odmicala, postale su primetne ne samo razlike u stavovima, već i lične netrpeljivosti među srpskim rukovodiocima:

SLOBODAN MILOŠEVIĆ: Zašto ste juče ubili potpredsednika Vlade? To vam uopšte nije trebalo.

RADOVAN KARADŽIĆ: Uhapsili smo čoveka i kaznićemo ga. Mi ćemo uraditi kako se dogovorimo; pogotovo ako budemo u situaciji da ugrožavamo maticu, Srbiju ili Crnu Goru; mi ćemo „odvezati svoj čamac“ u tom smislu da nema odgovornosti.

SLOBODAN MILOŠEVIĆ: Nije reč o „odvezivanju čamca“.

DOBRICA ĆOSIĆ: Ko može da žrtvuje vas? Ko danas sme da donese odluku da žrtvuje srpski narod u Bosni i Hercegovini?

RADOVAN KARADŽIĆ: Ali, ja hoću vama da kažem jednu stvar: mi se zavaravamo da ćemo mi, u kasnijoj fazi, njima doskočiti.

SLOBODAN MILOŠEVIĆ: Već smo im doskočili kada stvar prenesemo u kasniju fazu; već smo ih ,,preveli žedne preko vode“; o tome se radi. ${ }^{24}$

\section{(...)}

SLOBODAN MILOŠEVIĆ: Ove granice s malim popravkama biće odlične granice. Koliko je procenata Bosne i Hercegovine u ovim granicama?

RADOVAN KARADŽIĆ: Oko 40\%.

SLOBODAN MILOŠEVIĆ: To će se povećati iznad 50\%, jer ima spornih $20 \%$. RADOVAN KARADŽIĆ: Sporni su Posavina i Podrinje. (Upadica: I Neretva). Neretva jeste sporna, ali mi možemo da živimo bez Neretve; bez Podrinja i Posavine ne možemo da živimo. ${ }^{25}$

SLOBODAN MILOŠEVIĆ: Ja ti kažem da ovo Alija neće prihvatiti.

RADOVAN KARADŽIĆ: Prihvatiće Alija sve ovo.

SLOBODAN MILOŠEVIĆ: Neće, ni govora! ${ }^{26}$

Kako nije uspeo da privoli svoje sagovornike, Milošević je jednostavno napustio sednicu: „Ja insistiram da se javnosti ne daju nikakvi izveštaji o razgovorima. Ne treba otvarati ,karte“. Ja ću nastojati da ne idem, a ako se steknu okolnosti da je to štetno za našu državu, onda ću da idem. Izvinjavam se, pošto moram sada da idem, vi nastavite ${ }^{6 .}{ }^{27}$ Pritisnut između ovih odmeravanja snaga, Dobrica

\footnotetext{
${ }^{23}$ Isto, I, 72-73.

${ }^{24}$ Isto, I, 94.

${ }^{25}$ Isto, I, 112.

${ }^{26}$ Isto, I, 116.

${ }^{27}$ Isto, I, 129.
} 
Ćosić je sve više podsećao na neki od likova iz svojih romana, opterećenih tragikom srpskih nesloga: „Očigledan je sukob srpskog, prekodrinskog iskustva, po kome nema dogovora, prava i slobode sa Muslimanima i Hrvatima, i srpske, srbijanske vere u prava, principe, sopstvenu veštinu da se opstane i u najtežim okolnostima. Po istorijskom iskustvu Srbi su nejedinstven narod. Ni sadašnji interesi nisu nam u svemu saglasni. To nejedinstvo $u$ istorijskom iskustvu, uz sadašnje razlike, može biti kobno po budućnost srpskog naroda kao celine [...] Srbi iz Republike Srpske i Srbi iz Republike Srpske Krajine otišli su razočarani i nesrećni iz 'okrugle sobe' Palate Federacije, u kojoj je formalno rasturena SFRJ i u kojoj se danas možda raspukla srpska nacija, odnosno njeno političko jedinstvo". ${ }^{28}$

\section{Drugi čin: Ženevski dvoglasi (10-12. januar 1993)}

Ovako sastavljena srpska delegacija nije mogla da se postavi ni konstruktivno, niti nedvosmisleno. Tako je drugo plenarno zasedanje u Ženevi, održano 10. januara, prošlo bez pomaka. Hrvatska strana je ponovo iskazala spremnost da potpiše oba dokumenta, dok su druge dve nastojale da jedna drugu nadmudre. Bosanska strana je ponovila da prihvata ustavne principe, ali je Radovan Karadžić zahtevao njihovu korekciju, pa je čitav dan utrošen na sravnjivanje ovih verzija. ${ }^{29}$ Oven je opisao Karadžićevu nepokolebljivost u izveštaju Butrosu Galiju: „Kada je stigao, bio je u defanzivi, ali i dalje odlučan da istraje protiv naših ustavnih principa. Milošević je tokom ručka predložio formulu za spasavanje obraza - spajanje prva dva ustavna principa iz predloga, bez naročitih promena. Uveče u hotelu De Berže fasada srpskog jedinstva je napukla i Vens i ja smo bili svedoci Ćosićevih, Miloševićevih i Bulatovićevih navaljivanja na bosanske Srbe, među kojima je bio i general Mladić, da počnu da ozbiljno pregovaraju. [...] Bez pritiska iz Srbije i Crne Gore bosanski Srbi ne bi popustili ni za milimetar, budući da nisu bili pragmatičari kao Milošević, već ideolozi, srpski nacionalisti koji nisu želeli nijednog Muslimana na teritoriji kojoj su težili, a ako je moguće nijednog Hrvata takođe. [...] Nakon što je Milošević razjasnio da Beograd neće nastaviti da podržava bosanske Srbe, i pošto se Mladić uverio u to, umorni, nekoherentni i ponešto slomljeni Karadžić je pristao narednog dana. [...] Međutim, nije potpisao, insistirajući da se i ovo pitanje razmotri na skupštini na Palama. Ovaj mali napredak je međutim održao konferenciju, jer smo na tri predočena dokumenta imali šest potpisa - Hrvati su potpisali ustavne principe, mapu i obustavu neprijateljstava, Muslimani su potpisali ustavne principe i obustavu neprijateljstava. Srbi su potpisali obustavu neprijateljstava“ “. ${ }^{30}$

Kada je izgledalo da će doći do napretka u ovom pogledu, pojavio se veliki problem na relaciji između hrvatske i bosanske delegacije. Taj tinjajući

${ }^{28}$ D. Ćosić, Piščevi zapisi 1992-1993, 241. Više u: Vladimir Petrović, „Odnosi unutar srpske političke elite i krah Vens-Ovenovog plana za BiH“, Istorija 20. veka, br. 1, (2012), 9-26.

29 Izveštaj generalnog sekretara UN o aktivnostima na Konferenciji, u: V. Petrović, Srpske političke elite i Vens-Ovenov plan I, 177-179.

${ }^{30}$ D. Owen, Balkan Odyssey, 93. Beleške sa plenarnog sastanka u: B. Ramcharan, The International Conference on the Former Yugoslavia: Official Papers, II, 1309-1311. 
sukob je detoniran bombom koja je eksplodirala 11. januara u komandi Armije BiH u Gornjem Vakufu, a zatim se proširio na čitavu dolinu Lašve. ${ }^{31}$ Bilo je teško oteti se utisku da strane u konfliktu nastoje da ,poprave“ situaciju na terenu i time ojačaju svoje pregovaračke pozicije, ali je posledica bila privremeni prekid pregovora, tokom kojeg je u Sarajevu ovu tematiku raspravljalo Predsedništvo BiH koje je zasedalo u proširenom sastavu 11. januara. Sednicama ovog tela je dominiralo kako očajanje zbog razvoja događaja u Bosni, tako i uzajamno optuživanje. Stranka demokratske akcije (SDA) je smatrala da Hrvatska demokratska zajednica (HDZ) rastura Bosnu do kraja, a HDZ da SDA Bosnu monopoliše, pa je tako član Predsedništva Miro Lasić insistirao „da prvo vidimo šta se to događa u Ženevi. Moram da kažem da sam vrlo nezadovoljan. Ja sam potpuno neinformiran o stavovima i potezima naše delegacije u Ženevi, [...] da se radi o budućnosti Bosne i Hercegovine, a da neko ko je član kolektivnog šefa države pojma o pojmu nema. Predsjednik Predsjedništva vuče i neke poteze, za koje ne znam je li ih vuče kao legitimni šef svog naroda ili kao predsjednik Predsjedništva“"32

Otuda je sada i bosanska strana u Ženevi na drugoj plenarnoj sednici 12. januara govorila u dvoglasu, koji su kopredsednici zbunjeno posmatrali: „G. Silajdžić je izjavio da se, čak i dok pregovori traju, Sarajevo granatira i da ljudi ginu. Ljudi takođe umiru od gladi i hladnoće. Izjavio je da je najhitnije pitanje da se svo teško naoružanje stavi pod kontrolu Ujedinjenih nacija. [...] G. Boban je zahtevao da se dâ reč premijeru Bosne i Hercegovine g. Akmadžiću. On je toplo pozdravio mirovne napore kopredsedavajućih [...] Posle izjave da nema konsenzusa o sastavu delegacije Bosne i Hercegovine, o kojoj mogu odlučiti samo ljudi u zemlji, on je naglasio da je delegacija bosanskih Hrvata prihvatila dokument koji su kopredsedavajući predložili, i apelovao je za napore da se strane približe u stavovima". Situaciju je dodatno zamagljivalo držanje Tuđmana, Ćosića i Miloševića na ovoj sednici: „Predsednik Tuđman je izrazio iznenađenje što, posle svih napora, još nema dogovora o ustavnim principima. On je primetio da to može značiti ne samo nastavljanje rata, već njegovo širenje. Pomenuo je dogovor koji je inicirao između Republike Hrvatske i Savezne Republike Jugoslavije, i insistirao je da kopredsedavajući iskoriste svoje dobre usluge da se normalizuju odnosi između dve države“. Slično su se postavili i predsednici SRJ, Srbije i Crne Gore koji su uzeli učešća u radu ove sednice, podržavši predložene ustavne principe. ${ }^{33}$

${ }^{31}$ ICTY Judgment, Prosecutor v Dario Kordić i Mario Čerkez, (26 February 2001): para 559-563. https://www.icty.org/x/cases/kordic_cerkez/tjug/en/kor-tj010226e.pdf, 178-179. Više o ovom sukobu u: Arsen Milašinović, "The Croat-Bosniak War: The Select Findings of the Recent Regional Historiography", Istorija 20. veka, br. 1, (2021), 197-214. Predistorijom sukoba bavio se Mijo Beljo, „Sukobi Armije Republike Bosne i Hercegovine i Hrvatskoga vijeća obrane u Gornjem Vakufu tijekom 1992. godine“, Časopis za suvremenu povijest, br. 2, (2016), 389-410.

32 „Magnetofonski snimak 183. sjednice Predsjedništva Republike Bosne i Hercegovine, održane 11. januara 1993. godine“, u: Tomo Šimić, prir., „Dokumenti Predsjedništva BiH 1991.-1994“, National Security and the Future, vol. 8, no. 2, (2007), 7.

${ }^{33}$ Izveštaj generalnog sekretara UN o aktivnostima na Konferenciji, u: V. Petrović, Srpske političke elite i Vens-Ovenov plan I, 180-182. 
Ove izjave, međutim, nisu verno odražavale stav bosanskih Srba, a natezanja sa njima opisao je Dobrica Ćosić: „Izuzetno dramatični pregovori o prihvatanju ustavnih principa nove Bosne i Hercegovine i mapa deset autonomnih provincija, po kojima oko petsto hiljada Srba treba da živi u provincijama u kojima će Muslimani biti većina a u nekim Hrvati, što Karadžić ne može da prihvati. [...] Dva dana i jednu noć smo se sporili, svađali, usaglašavali [...] Milošević, Bulatović i ja. S ministrom Đukićem i našim političkim i vojnim savetnicima, opredelili smo se za prihvatanje Vensovog i Ovenovog plana, žrtvujući neke značajne srpske interese da bismo postigli mir i oslobodili se sankcija. U tim pregovorima Milošević se pokazao kao vanredan taktičar u političkoj i diplomatskoj bici. [...] Prvog dana nismo uspeli da ubedimo Karadžića, Koljevića, Krajišnika i Buhu. To su fanatični i bandoglavi političari. Nisu napuštali svoje pozicije ni pred kakvim argumentima, jer su bili duboko svesni nepravde koja im se čini. Nosili su ih borilačka vera njihove vojske i odgovornost pred njom i narodom za politički ishod tog užasnog rata. Milošević je snagom političke logike argumenata, ali i grubim pretnjama, ali i uvredama, nastojao da ubedi Karadžića i drugove da prihvate ustavne principe i mape koje su za njih spornije od ustavnih principa. [...] Ujutru sam saznao da su vođe Republike Srpske u svanuće otišle u svoj hotel, neubeđeni i očajni [...] Najzad smo morali da zaključimo: na završnoj sednici delegacija kojima predsedavaju Vens i Oven, ja moram da iskažem nesaglasnost sa stavovima predstavnika Republike Srpske i suprotstavim se Karadžiću i drugovima. [...] Napustio sam Ženevu, neuveren u blizak mir u Bosni i Hercegovini“"34

Suočeni sa ovakvom kakofonijom, Vens i Oven nisu imali mnogo izbora nego da predlože desetodnevnu pauzu i zakažu novu rundu pregovora za 22. januar. Istovremeno, kopredsedavajući su se upustili u široku diplomatsku inicijativu da bi dobili međunarodnu podršku i izvršili pritisak na strane u konfliktu. Lord Oven je još ranije brifovao predstavnike Evropske zajednice insistirajući da, iako ima još prostora za manje promene na mapi, „Dvanaestorica treba da iskoriste uticaj na one strane da prihvate ono što je na stolu. Bosanskim Srbima treba nedvosmisleno staviti do znanja da je koncept države u državi potpuno neprihvatljiv međunarodnoj zajednici. Izetbegovića sa druge strane treba ubediti da je ovo najbolji predlog koji će bosanski Muslimani dobiti““. ${ }^{35}$ Dok su članice Evropske zajednice makar deklarativno bile ujedinjene iza ovog plana, otvarao se procep među vanevropskim silama. Deklarativno podržavajući plan, Rusija je smatrala da je došlo vreme da se Srbima pored „štapa“ ponudi i ,šargarepa“ 36

S druge strane, dolazeća američka administracija Bila Klintona je najavila niz mogućih mera, od podizanja embarga na oružje do bombardovanja srpskih pozicija. Međutim, kako je iza kulisa tvrdio Entoni Lejk, savetnik za naci-

\footnotetext{
${ }^{34}$ D. Ćosić, Piščevi zapisi 1992-1993, 245.

35 "Extract from Report by UK Mission, Geneva, on Lord Owen's briefing of EC representatives", 5 January 1993, u: D. Owen, Bosnia-Herzegovina, 221.

36 "Note delivered by Russian Ambassador, Geneva, to Co-Chairmen", 10 January 1993, u: D. Owen, Bosnia-Herzegovina, 224.
} 
onalnu bezbednost, nova administracija je i dalje podržavala Vens-Ovenov plan, a da je svrha ovih najava bila samo u funkciji pritiska na srpsku stranu da se saglasi sa mirovnim aranžmanom. ${ }^{37}$ Kopredsedavajući nisu bili potpuno uvereni $\mathrm{u}$ to, a brinuo ih je i mogući kolateralni efekat takve retorike na bosansku stranu, koja je ovakve američke izjave doživljavala kao inspiraciju da istraje u odbijanju mirovnog plana do eventualne vojne intervencije. Svesni da podrška njihovom planu slabi, Vens i Oven su se razleteli po Balkanu u pokušaju da privole sve strane na pristanak pre nego što istekne vreme.

\section{Dugi intermeco: Sarajevo, Zagreb, Pale, Beograd (13-22. januar 1993)}

Nikakvo smirivanje se, međutim, nije dogodilo u ovom periodu, a sukob se širio na više tačaka u Bosni i Hercegovini, i to između sve tri strane. Tako su sastancima Predsjedništva $\mathrm{BiH}$ potpuno dominirale rasprave o sukobu na tom prostoru i u dolini Lašve, na jedvite jade je usvojen sastav delegacije za drugu rundu pregovora $u$ Ženevi, i to tek nakon što su Vens i Oven posetili Sarajevo da bi posredovali, pre svega između predsednika Izetbegovića i premijera Akmadžića. ${ }^{38}$ Delegacija je sastavljena tako da odražava što širi konsenzus između SDA i opozicionih partija: Alija Izetbegović i Haris Silajdžić iz SDA, Muhamed Filipović iz Muslimanske bošnjačke organizacije (MBO), Miro Lazović iz Socijaldemokratske partije (SDP), kao i visoki oficiri Armije BiH Stjepan Šiber i Sefer Halilović. ${ }^{39}$ Primetno je bilo odsustvo članova HDZ iz ove delegacije. Ne samo što Franjo Boras i Miro Lazić, kao hrvatski članovi Predsjedništva, nisu uzeli učešća, već je premijer BiH Mile Akmadžić pratio kopredsedavajuće na putu iz Sarajeva u Zagreb na njihov sastanak sa Tuđmanom i Matom Bobanom, da ne ostane nikakve sumnje na čijoj je strani. Na tom sastanku Boban je izrazio sumnje $\mathrm{u}$ iskrenost i dobre namere bosanske vlade. ${ }^{40}$

Izveštavajući francuskog predsednika Miterana o pomacima tokom ovih sastanaka, lord Oven je sumirao: „Predsednik Tuđman je rekao da ne može dići ruke od Posavine i dozvoliti da se ujedini sa banjalučkom provincijom. Međutim, mogao bi se saglasiti sa koridorom širokim oko 20 kilometara kroz Posavinu, ukoliko bi se sličan koridor napravio od Bihaća do Livna. Kada je ovaj predlog predočen predsedniku Izetbegoviću, on ga je odmah odbio. Smatrao je da

\footnotetext{
37 "Report by Robin Renwick, UK Ambassador, Washington", 14. January, u: D. Owen, BosniaHerzegovina, 228.

38 "Report by Lord Owen's Private Secretary on Co-Chairmen's visits to Sarajevo and Zagreb", 20-21 January 1993, u: D. Owen, Bosnia-Herzegovina, 248.

39 „Magnetofonski snimak 185. sjednice Predsjedništva Republike Bosne i Hercegovine, održana 22. januara 1993. godine“, u: T. Šimić, $n$. d., 11.

40 "Report by Lord Owen's Private Secretary on Co-Chairmen's visits to Sarajevo and Zagreb", 20-21 January 1993, D. Owen, Bosnia-Herzegovina, 250-251. Nepoverenje između bošnjačkih i hrvatskih članova u organima vlasti Bosne i Hercegovine posejano je još početkom 1992. godine. Bosna i Hercegovina u vreme raspada SFRJ 1990-1992: tematska zbirka dokumenata, priredio Kosta Nikolić (Beograd: Institut za savremenu istoriju/Fond za humanitarno pravo, 2011), 61-83.
} 
bi to ohrabrilo koncept Velike Srbije. Mogao je prihvatiti samo neku saobraćajnicu. Moje sopstveno gledište je da on neće promeniti ovo viđenje čak i ako mu Srbi ponude još teritorije. U tom slučaju nećemo menjati našu mapu, pošto smo već jasno rekli da to nećemo raditi ako se sve tri strane ne slože. Mislim da će predsednik Izetbegović prihvatiti naše mape i preneti teret na Srbe da to isto urade. Da li ih se može ubediti da tako postupe, ne znam“. ${ }^{41}$

Oven nije ni mogao znati kakvo će biti srpsko stanovište, pošto to nisu znali ni oni. Narodna skupština Republike Srpske se na sednici održanoj na Palama 19. i 20. januara saglasila sa Karadžićevim prihvatanjem ustavnih principa za $\mathrm{BiH}$, ali su se poslanici ponovo pokazali tvrdim pregovaračima, beskompromisno zastupajući „neprolazno pravo na samoopredijeljenje“. Nisu se ustručavali od kritike članova delegacije. Radoslav Brđanin, koji je na prethodnoj sednici Ćosićevo ponašanje ocenio „kapitulantskim“, sada je proširio kritiku na celo rukovodstvo Savezne Repulike Jugoslavije (SRJ), preteći da dolazi vreme da se vidi „ko je vjera, a ko je nevjera“. ${ }^{2}$

Tako je mislila i potpredsednica Republike Srpske (RS) Biljana Plavšić, koja je takođe bila protiv ponuđenog plana: „U januaru, na Jovanjdan, ponuđen je našoj skupštini konstitutivni deo na razmatranje. Znam da je bio neki vremenski tesnac, jer ne bi Krajišnik zakazivao zasedanje na dan kada mnogi poslanici slave slavu. Dobro sam se pripremila za raspravu. Možda je to bila i najdetaljnija analiza ustavnog rešenja. Naravno da sam se prethodno konsultovala sa nekoliko ljudi koji su stručni za tu materiju, zato je moja analiza u skupštini imala odjeka. A ono što sam kao laik znala bilo je dovoljno da shvatim da se radi o kantonizovanoj teritoriji sa snažnom centralnom upravom. Takođe, bilo mi je jasno da je bez teritorijalnih rešenja deplasirano govoriti o konstitutivnom uređenju. Imali smo već dosta loših iskustava, pa je postojalo podozrenje $u$ vezi sa teritorijalnom ponudom. Bila sam za odbijanje konstitutivnog dela, ali da se traže mape. Zaključak Skupštine bio je mudriji i glasi - ne odbacuje se konstitutivno rešenje, a da li će biti prihvaćeno ili dobijeno, zavisi od teritorijalnih rešenja“" 43

Zapravo je u Bijeljini Momčilo Krajišnik pustio poslanike 'da se izduvaju’, a u realnosti je „Skupština Republike Srpske prihvatila ženevske pregovore uz izvesna uslovljavanja. Pobedio je pametni i vešti Radovan Karadžić...", tvrdio je Dobrica Ćosić. ${ }^{44}$ Radi približavanja stavova, pred odlazak na pregovore održan je 21. januara još jedan sastanak Saveta za usaglašavanje stavova o državnoj politici u Beogradu. Kao i bosansku stranu, i srpsku je pre svega brinulo pitanje mapa, čije su korekcije priželjkivali. Milošević je zato predložio da se odmah prihvate ustavni principi, kao i vojni papir, i predloži momentalan prekid

41 "Letter from Lord Owen to President Mitterrand following their meeting on 14 January 1993“, D. Owen, Bosnia-Herzegovina, 235.

42 Thomas Dodd Center, Robert J. Donia Collection, Bosnian Serb Assembly Sessions, Session 25, 19-20. 1. 1991, 16 https://archives.lib.uconn.edu/islandora/object/20009\%3As25transcript \#page/1/mode/2up (pristupljeno 24. 1. 2021).

${ }^{43}$ Biljana Plavšić, Svedočim, II (Banja Luka: Trioprint, 2007), 10-11.

${ }^{44}$ D. Ćosić, Piščevi zapisi 1992-1993, 265. 
vatre. ${ }^{45}$ Krajišnik se na prvi pogled složio: „Sigurno da je to najvažnije, ali ovaj rat, kako je rekao profesor Koljević, vodi se samo radi mapa. [...] Ako mape ne 'načnemo', bojim se da ćemo mi ispasti krivi što kršimo vojni sporazum, koga smo potpisali““. ${ }^{46}$ Milošević je smatrao da je mape moguće docnije korigovati, nezavisno od prekida vatre i budućeg povlačenja na granice provincija: „Pošto provincije nisu definisane nema vraćanja snaga u granice nedefinisanih provincija““ ${ }^{47}$ Rukovodstvo bosanskih Srba, međutim, nije bilo spremno da se upušta u taj rizik. Iako im je podrška iz Srbije bila nužna, bili su takođe svesni da ih Milošević ne sme pustiti niz vodu ako želi da ostane na vlasti. Oni su se ubrzano osamostaljivali. ${ }^{48}$

Razmimoilaženje između Miloševića i Karadžića pokušao je da premosti Ćosić. On je podsetio da ranije „nismo postigli načelnu saglasnost. To nas je veoma skupo koštalo u Ženevi. Danas ja mislim da smo mi postigli najviši stepen saglasnosti. [...] Predlažem da idemo u Ženevu sa tvrdim principima. A to je: ne možemo da prihvatimo postojeći predlog mapa; mi se moramo boriti odlučno za promenu te formacije koju su nam oni ponudili““.49

Kako za tim stolom, međutim, niko nikome nije verovao, pored delegacije bosanskih Srba, u Ženevu su otputovali i predsednici SRJ, Srbije i Crne Gore, kao i njihovi ministri inostranih poslova. Sta ih je tamo čekalo sutradan, opisao je lord Oven 22. januara Džonu Mejdžoru na sastanku u čuvenoj Dauning ulici 10: „Pod pretpostavkom da dr Karadžić kaže 'da' ustavnim principima, onda nastavljamo plenarnu sednicu što pre [...] Pregovori će se koncentrisati na mapu predloženih deset provincija. Srbi i Muslimani će tražiti više teritorije. Znamo od Miloševića da će biti dogovora ako bude kopnenog koridora kroz Posavinu koji bi povezao Banja Luku sa Srbijom. Znamo da je Izetbegović nepokolebljivo protiv toga, verujući da će to izbaciti naš predlog iz ravnoteže i usmeriti ga ka eventualnoj Velikoj Srbiji, što je teško osporiti. Nećemo promeniti mape ukoliko se sve tri strane ne slože. [...] Mnogo će zavisiti od toga kako će Muslimani i Srbi reagovati na poruke koje dolaze iz Klintonove administracije“. Oven je izložio nekoliko scenarija: „Ako se sve tri strane saglase [...] snage koje učestvuju u UN naporima bi pod promenjenim mandatom uzele učešća u implementaciji prekida neprijateljstava. Ako i Muslimani i Srbi odbiju mape, i dalje bi bilo poželjno nastaviti pregovarački proces. Možda bi mogli da ubedimo predsednika Klintona [...] u opasnosti ukidanja embarga na oružje za Muslimane [...] što bi nam dalo malo više vremena za pregovaranje. Po mom sudu, podići embargo bi značilo učiniti dalje pregovore potpuno nemogućim. Izetbegović bi bio ohrabren da blokira pregovore i nastavi da se bori. Rusi bi bili u obavezi da dozvole da do Srba dođe sofisticirano oružje, a Velika Britanija bi morala da

\footnotetext{
${ }^{45}$ V. Petrović, Srpske političke elite i Vens-Ovenov plan I, 191.

${ }^{46}$ Isto, I, 226-228.

${ }^{47}$ Isto, I, 234.

${ }^{48}$ Nina Caspersen, Contested Nationalism: Serb Elite Rivalry in Croatia and Bosnia in the 1990s (New York: Berghahn Books, 2009), 146.

49 Tribunal: Milošević, dokaz P469.39. Stenografske beleške sa proširene sednice Saveta za usaglašavanje stavova o državnoj politici, 21. januar 1993, Beograd, 70.
} 
razmisli da li da uzme učešća u daljim naporima UN na terenu. Ako mi kao kopredsedavajući steknemo utisak da bilo Srbi ili Muslimani blokiraju uspešne pregovore onda ćemo odneti ovaj mirovni paket Savetu bezbednosti na prihvatanje i tražiti mere za njegovu implementaciju. Ako Srbi blokiraju, implementacija bi iziskivala da Savezna Republika Jugoslavija, pod pretnjom totalne izolacije, zaustavi svu pomoć sem humanitarne bosanskim Srbima. Ako SRJ to odbije, pored potpune izolacije Savet bezbednosti bi trebao da odobri vojne mere protiv oružanih snaga bosanskih Srba. [...] Sve što je potrebno je preokretanje odnosa snaga protiv Srba u korist muslimanskih i hrvatskih trupa na terenu. Ovo se može uraditi selektivnim upotrebom vazdušne moći [...] ali samo ukoliko SB podrži mirovni plan. Sve drugo bi bilo neodgovorno i ispalo bi da Zapad podržava džihad. Postoji i rizik da bi takva intervencija uvela Vojsku Jugoslavije u rat, ali taj rizik po meni vredi podneti, jer ako su spremni da u ovakvim okolnostima udare na međunarodnu zajednicu, svakako su spremni da to urade na Kosovu. Bolje je suočiti se sa time u BiH, koja je već u haosu nego da čekamo da Kosovo eksplodira, a sa njim i ceo Balkan. Ako Muslimani blokiraju mirovno rešenje onda argumenti za pooštravanje embarga na oružje postaju očigledni““. ${ }^{50}$

Izgledalo je da su sve opcije pokrivene i da se drama privodi kraju. Vens i Oven su pripremili nove, neznatno izmenjene predloge mirovnog paketa. ${ }^{51} \mathrm{Na}-$ livpera su bila na stolu, dokumenta umnožena i odštampana, a Palata nacija, sedište Ujedinjenih nacija u Ženevi, samo je još čekala buduće potpisnike.

\section{Treći čin: Ženevski troglas, 23-30. januar 1993.}

Umesto potpisa, delegacije su po prispeću ponovo otvorile pregovore iznošenjem starih i novih zamerki na ponuđeni plan. Sticao se utisak da je mnogim pregovaračima Ženeva uveliko dozlogrdila. Dobrica Ćosić o njoj svakako nije imao lepih reči: „Ženeva. Voze me blindiranim automobilom od aerodroma do hotela, od hotela do Palate nacija, jedne od najružnijih evropskih zgradurina. [...] Karadžić je prihvatio predlog kopredsednika Vensa i Ovena po odluci Skupštine Republike Srpske, to jest, po mojoj, Miloševićevoj i Bulatovićevoj uceni, posle ultimatuma, koji su nam pre desetak dana, u pola dva noću, saopštiti lord Oven i Sajrus Vens. Tu noć kada se odlučivalo hoće li Srbi iz Republike Srpske pristati da se odreknu svoje države koju su počeli da stvaraju i da pristanu na život u nakaznoj i veštačkoj BiH, hoće li pristati da žive u pasivnim 'provincijama', van kojih bi ostalo 48 procenata njihovih sunarodnika, hoće li sami poništiti cilj svoje oslobodilačke borbe, a na sve to smo ih mi iz SR Jugoslavije primorali, tu noć nikada neću zaboraviti“ “. ${ }^{5}$

Otuda su pregovori ponovo zastali, a Ovenu je ostalo samo da pribeleži: „U Ženevi smo u subotu 23. januara počeli treću plenarnu sesiju u prisustvu

50 "Draft Letter from Lord Owen to Prime Minister John Major", u: D. Owen, BosniaHerzegovina, 259-261.

${ }^{51}$ Nacrt mirovnog plana predložen 30. januara 1993. u: V. Petrović, Srpske političke elite $i$ VensOvenov plan I, 249-259.

${ }^{52}$ D. Ćosić, Piščevi zapisi 1992-1993, 269. 
svih strana. Bio je to težak sastanak. [...] Karadžić je istakao da je bezbednost srpskog naroda glavna briga njegove vlade [...] tvrdeći da bi po postojećim mapama 650.000-700.000 Srba ostalo u provincijama koje bi kontrolisali Hrvati i Muslimani. Hteli su referendum o našim predlozima. Odgovorio sam Karadžiću da to nije moguće dok rat traje. Ustav Bosne i Hercegovine bi omogućio promenu granica između provincija; ono što nam je bilo potrebno sada, uz trodelni paket predloga, bio je dogovor o prelaznoj vladi““.53 U tom duhu su se bošnjačka i hrvatska strana 24. januara dogovorile o sistemu privremene uprave u njihovih šest provincija koje bi pored guvernera iz jednog, i viceguvernera iz drugog etniciteta, imale i desetočlani multietnični izvršni organ. ${ }^{54}$ Tako su se Izetbegović i Silajdžić sa jedne, a Boban i Akmadžić sa druge strane, zapravo dogovorili o granicama i privremenoj upravi u pet provincija (Mostar, Bihać, Zenica, Tuzla, Posavina), dok je Travnik ostao predmet sporenja. Srpska strana je označena kao kočničar mirovnog procesa.

Pod takvim pritiskom, srpski predstavnici su po ustaljenom običaju otišli 'po pamet' u Beograd sa idejom ujedinjenja svih srpskih zemalja: „Sastanak smo održali u Palati Federacije sa Dobricom Ćosićem, koji nije bio previše naklonjen našoj ideji. Smatrao je da politički nije dobar trenutak za srpski narod da pokazuje svoju želju za ujedinjenjem. Posebno da nije dobro da u ovom trenutku to pokazuje tako što bi vojno pomagao Srbe preko Drine. Ćosić se upravo vratio iz Grčke. Kaže, i Micotakis i Karamanlis smatraju da treba pričekati. Takvi saveti dolaze i od ruskog ambasadora Šikina, kaže: vreme radi za nas, treba mirotvorno delovati, ostaviti krivicu na Hrvatima i Muslimanima. [...] Imamo utisak da naša braća preko Drine još uvek veruju da su bolji mali potezi i taktički manevri, nego jedno javno, složno i odlučno istupanje. Pitanje je da li ćemo uspeti da ih ubedimo i nagovorimo da Srbi treba konačno da se izjasne o svojim nacionalnim ciljevima. [...] Videćemo do povratka naših iz Ženeve da li ćemo uspeti da podstaknemo raspoloženje za jednu svesrpsku skupštinu“, pisao je Nikola Koljević. ${ }^{55}$

$\mathrm{U}$ međuvremenu su u Ženevi nastavile sa radom radne grupe, ali bez velikih pomaka. Bosanska delegacija je imala niz primedbi na regulisanje odnosa centralne vlasti sa pokrajinskim i na način prenosa vlasti. ${ }^{56}$ Koljević je u dnevniku zabeležio: „Od naših iz Ženeve nikakve naročite vesti. I danas se radi na detaljima mapa i na ideji o prelaznoj vladi. To pokazuje u stvari neozbiljnost ove faze konferencije. Od Viktora Andrejeva ${ }^{57}$ sam prekjuče u razgovoru dobio informaciju da 'neko' priprema Konferenciji kraj. [...] Po povratku iz Han-Pijeska nalazim se sa Karadžićem. I on sumnja u to da bi moglo doći do nekog značajnog ishoda Konferencije, ali misli da je za sada najvažnije da krivica ne bude na nama“" ${ }^{58}$

\footnotetext{
${ }^{53}$ D. Owen, Balkan Odyssey, 93.

54 "ICFY Memo from Peter Hall", 24 January 1993, u: D. Owen, Bosnia-Herzegovina, 270.

${ }^{55}$ Nikola Koljević, Stvaranje Republike Srpske. Dnevnik 1993-1995, I, (Beograd: Službeni glasnik, 2008), 65.

56 "ICFY Memo from Peter Beshar to Co-Chairmen on Drafting Session with Mr Trnka of Bosnian Government", u: D. Owen, Bosnia-Herzegovina, 276-278.

${ }^{57}$ Koordinator u Službi za civilne poslove pri komandi UNPROFOR-a u Sarajevu.

${ }^{58}$ N. Koljević, $n$. d., 57.
} 
Sumirajući stanje pred poslednju plenarnu sednicu zakazanu za 30. januar, lord Oven je priznao da „nismo sigurni da li će Predsednik Izetbegović ili dr Karadžić potpisati u subotu: obojica se odmeravaju i čekaju na prvi potez ovog drugog. Ni jedan ne želi da ispadne taj koji je razbio konferenciju ili odbio da potpiše“".59 Na Ovenovo iznenađenje, međutim, „na trećoj plenarnoj sednici postignut je iznenađujući napredak. Posle odvojenih razgovora sa Izetbegovićem i Karadžićem uspeli smo da ih spojimo i došlo je do pravog pomaka u nacrtu za prelaznu vladu. Složili su se oko male centralne oblasti Sarajeva kojom bi se upravljalo konsenzusom. U međuvremenu, Silajdžić i Boban su se dogovorili o provincijskom sistemu uprave. [...] Nismo bili sigurni da li će predsednik Izetbegović i dr Karadžić potpisati u subotu. Nijedan nije želeo da bude taj koji će rasturiti Konferenciju ili odbiti da potpiše. Nameravali smo da odmah posle subote referišemo Savetu bezbednosti i da tražimo podršku za naš sveobuhvatan plan, ali smo želeli maksimalan pritisak na onoga koji ne potpišse“. ${ }^{60}$

Kopredsedavajući su sa velikom energijom zastupali svoj plan: „Na poslednjoj plenarnoj sednici Sajrus Vens je rekao da je sve ovo potvrdilo naše stanovište da su ponuđene mape pravedne i zasnovane na osnovnoj premisi da će Bosna i Hercegovina ostati suverena, multietnička država. Mape nisu predstavljale rezultat etničkog čišćenja već pokušaj da se ono preokrene, i balansirale su pitanje teritorije, prirodnih i industrijskih resursa. Ja sam u svom govoru rekao da ćemo ovaj spor preneti pred svetski parlament i izrazio nadu da će svi pregovarači doći u Njujork i predstaviti svoje argumente pred članicama Saveta bezbednosti. Sve tri strane su potpisale ustavne principe; bosanski Hrvati, a donekle na naše iznenađenje i bosanski Srbi, potpisali su dogovor o okončanju neprijateljstava. Izetbegović, koji je ranije pristao na njega, sada je rekao da ga rezerve u odnosu na teško naoružanje sprečavaju da ga potpiše. Po pitanju mapa Karadžić je postao daleko bliži potpisivanju nego što smo predvideli, i uveren sam da bi ih potpisao da je Izetbegović to uradio. [...] Vens i ja smo smatrali da je Milošević rekao Karadžiću da se nagodi““. ${ }^{61}$

Nikola Koljević ovako opisuje kulminaciju tog dramatičnog lova na potpise: „Principe navodno svi potpisuju. Hrvati uostalom potpisuju sve od samog početka, ali ovaj put ustavne principe potpisuju i naši. Za Muslimane se, opet, ne zna - neki tvrde da su potpisali, neki da nisu. Mi smo odlučili da potpišemo principe da bismo sa sebe skinuli taj deo odgovornosti za propast Konferencije. Naši traže da se izvrše korekcije na mapama i da se narodno mišljenje proveri na referendumu. Znači, demokratski. Na to Vens i Oven sklanjaju mape i ne dozvoljavaju nikakvu raspravu. Ali podmeću vojni papir. Naši potpisuju vojni papir. Ne znam da li je uklonjena ona klauzula o kontroli oružja i povlačenju, ali naši u svakom slučaju potpisuju, a Muslimani ne potpisuju. Pitanje je

\footnotetext{
${ }^{59}$ COREU Report from Lord Owen on Peace Talks on Bosnia, 29 January 1993, u: Lord Oven's Papers https://libguides.liverpool.ac.uk/ld.php?content_id=31121178, p. 88 (pristupljeno 24. 1. 2021).

${ }^{60}$ D. Owen, Balkan Odyssey, 92.

${ }^{61}$ Isto, 94.
} 
da li je to opet neka muslimanska igra, pa će i oni potpisati kasnije, ili je doista stav koji sarajevski radio neprestano ističe: da niko nema pravo da potpiše bilo šta što nije unitarna Bosna. Ostaje nam da vidimo“ ${ }^{62}$

Tako je kulminacija januarskih pregovora prerasla u antiklimaks. Izgledalo je da je mir na dohvat ruke, a onda se sve neočekivano vratilo na polaznu tačku. „Mnoge diplomate i novinari na Konferenciji su bili mišljenja, kao i mi, da bi tog dana, da je Izetbegović potpisao mape, to uradio i Karadžić. Svakako smo bili bliži sporazumu no što je iko od nas mogao i da zamisli pre nedelju dana. Zašto Izetbegović nije potpisao?“, pitao se Oven, dok su protagonisti silazili sa ženevske pozornice, pravo na aerodrom, pa u mrak sopstvenih bunkera i komandnih mesta. ${ }^{63}$

\section{Iza kulisa}

Odmah po povratku u Sarajevo, Alija Izetbegović je članovima Predsjedništva BiH izneo svoje viđenje mirovnog procesa: „Mapu nismo prihvatili, kao što znate, znate i razloge, i mislim da se ne ljutite što je nismo prihvatili. [...] Kako su razgovori tekli, ona se sve više deformisala i sve više išla, naime, deformirala se u pravcu usvajanja i prihvatanja etničkog kriterija u tolikoj mjeri, da se konačno pretvorila skoro u etničku kartu i natezanja oko etničkih granica. Eto, u takvoj situaciji, po našem mišljenju, Konferencija nije uspjela, razišla se, nema saglasnosti. Ova dvojica (Vens i Oven - prim. V. P.) su uzeli te papire i otputovali za Njujork da to izlože Savjetu bezbjednosti, da mu predlože da on bude arbitar u ovome“. 64

Izetbegović je saradnicima izneo i svoje dileme: „Što se mene lično tiče ja bih razmišljao o tome da potpišem taj papir ne bi li skupili taj narod koji se polako gubi po svijetu i koji vrlo teško podnosi izbjeglištvo, a s druge strane, polako se gubi. Neki praktični razlozi su me naveli da ozbiljno razmišljam da prihvatimo tu mapu ako bi se omogućilo da se naših 6-7 stotina hiljada ljudi vrati u svoje domove pa da se u nekoj drugoj etapi nastavimo dalje boriti imajući tu državu koja je dosta da kažem, na neki način, difuzna, ali imamo jedan okvir. Da uzmemo to kao neki prvi korak ka tome da se ponište rezultati rata. Jer mi nismo dobili vojnu pobjedu da bi mogli da diktiramo uvjete, uspjeli smo da odbranimo jedan dio teritorije. [...] To je moje mišljenje, naravno, ja je ne bih prihvatio svakako bez konsultacije sa vama, ali dajem jedan svoj lični sud o tome“".65 Time je podgrejao bojazni da u stvari i sam ide na ruku daljem rastakanju Bosne radi stvaranja ekskluzivno muslimanskog entiteta, u skladu sa grafitom koji se tih dana pojavio na jednoj državnoj zgradi: „Potpiši Alija, neka je naša, pa makar velika ko avlija“، ${ }^{66}$

\footnotetext{
${ }^{62}$ N. Koljević, $n$. d., 58.

${ }^{63}$ D. Owen, Balkan Odyssey, 95.

${ }^{64}$ „Magnetofonski snimak sjednice Predsjedništva RBiH i predsjednika stranaka održane 2. februara 1993. godine“, u: T. Šimić, $n$. d., 13-14.

${ }^{65}$ Isto, 15.

${ }^{66}$ Intervju autora sa Muhamedom Filipovićem, Sarajevo, 10. 7. 2016.
} 
Muhamed Filipović se tome kategorički protivio: „Mislim da naša delegacija nije imala drugog izlaza u situaciji u kojoj smo se našli, nego da ostanemo dosljedni kod onog što je bio naš mandat. Naš je mandat bio imperativ. Mi nismo smjeli pristati ni na kakvu soluciju koja podrazumijeva etničku podjelu BiH. Pošto je ova karta koju su predložili ko-predsjedavajući praktično na zaobilazan način ipak inaugurirala i uvela princip etničke podjele kao osnovu rješenja podjele $\mathrm{BiH}$. [...] mi nismo imali drugog izlaza nego da ostanemo dosljedni kod toga da odbijemo da $\mathrm{BiH}$, da njena budućnost bude definirana takvom unutrašnjom podjelom i konstitucijom provincija koje imaju veoma velike oblasti, koje će funkcionirati kao paradržava. Jednostavno, mi ne možemo prihvatiti nikakvu soluciju koja legalizira etničko čišćenje i eliminira mogućnost da se naš narod vrati na svoje mjesto i da tako kažem obezbijedi svoja prava“. On je posebno osuđivao Akmadžića: „Mi i nemamo predsjednika Vlade! Nama su udarili nož u leđa u Ženevi [...] Oprostite, ali naša pozicija se srušila tamo. Mi smo je gradili tri i po mjeseca a on ju je srušio onoga momenta kada je došao i izjavio da ne priznaje da postoji jedinstvena i zajednička delegacija BiH. A predsjednik je Vlade $\mathrm{BiH}$ ! On je delegitimiran“. ${ }^{67}$ Izetbegović se pak pomirljivo izražavao ovim povodom, nastojeći da ne produbljuje sukob i zalažući se za kohabitaciju između Predsjedništva i Akmadžićeve vlade.

Izetbegović je sednicu zaključio jezikom političkog realizma: „Protiv nas se našla jedna strašna mašina, srušila nam je tu državu, mi sad to pokušavamo koliko možemo u takvoj situaciji da to konsolidiramo. To je situacija u kojoj mi pokušavamo da održimo se nekako na površini da ne potone taj brod što se zove Bosna. Jednostavno, bura i još brod šupalj na sto mjesta. Treba brod pokušati nekako da se iskrca $\mathrm{i}$ da se nekako dođe do obale - kako god. U toj situaciji ne možemo, unutra vlada priličan nered i na palubi i dole i svugdje $\mathrm{i}$ radi se koliko može“. ${ }^{68}$ Upozoravao je: ,Svijet nas ne pomaže, svijet nas, naprotiv, gura na pregovore. [...] Sad imamo nekakvu teritoriju slobodnu, otprilike $45 \%$ teritorije koja bi se možda mogla povećati za daljnjih 12-15 procenata, pa bi bilo $60 \%$ slobodne teritorije. Pa neka se za onih $40 \%$ dalje borimo političkim i drugim sredstvima. To je jedan modus. A drugi je modus da jednostavno rizikujemo i da kažemo idemo u nastavak rata, stvarajući jedan narodni front svih snaga koje se bore za $\mathrm{BiH}$, da otkažemo ljubav i razgovor sa svima spolja i da pokušamo se tu boriti. Ali meni je stalno slika geopolitičkog položaja Bosne kakav on jeste pred očima“" 69

Dok su ove dileme lebdele nad Sarajevom, i u Beogradu su se mišljenja razilazila. Kao što je Izetbegović smatrao da bi plan mogao biti prihvatljiv ukoliko bi podrazumevao brzo povlačenje suprotstavljenih snaga u zadate provincije i omogućio povratak izbeglica, tako je srpska strana strepela upravo od toga. Vladislav Jovanović je još na početku januarske faze pregovora iskazivao da

\footnotetext{
67 „Magnetofonski snimak sjednice Predsjedništva RBiH i predsjednika stranaka održane 2. februara 1993. godine“, u: T. Šimić, $n$. $d ., 17-18$.

${ }^{68}$ Isto, 24-25.

${ }^{69}$ Isto, 27.
} 
„osnovani strah od kvarenja demografskog sastava Bosne može da se realizuje. Reč je o tome da li bi ove provincije otežavale ili onemogućavale pravo, na primer, Muslimana da se slobodno nastanjuju u srpskim zemljama? Sećam se da je gospodin Karadžić svojevremeno ukazivao na tu opasnost". Milošević se sa ovim viđenjem nije slagao: „Ta opasnost ne postoji, neće oni da 'jure' tamo“. Međutim, njegov ministar spoljnih poslova je ostao neuveren: „Rečeno je 'pravo na slobodu kretanja'. To može da uključi i slobodu nastanjivanja, ako se drukčije ne kaže. Zbog toga, to treba imati u vidu da se ne bi desili nesporazumi“. ${ }^{70}$ Izgleda da su januarski pregovori samo produbili ove bojazni u rukovodstvu bosanskih Srba. Stoga je nastavljeno usaglašavanje stavova početkom februara: „Danas krećem u Beograd da se savetujemo pred polazak u Njujork. Nije odlučeno još ko će da ide, ali znam da tamo neće biti veselo. Pritisak će biti ogroman“, zapisao je u dnevniku Nikola Koljević. ${ }^{71}$

Ovenove reči zaista jesu nagoveštavale takav pritisak: „Gotovo pet meseci pregovaramo bez prestanka od jutra do mraka, ovde u Ženevi, u Sarajevu, u Zagrebu i Beogradu. Sve ovo vreme besni divljački rat. Groteskne zloupotrebe ljudskih prava prolaze nekažnjeno, a posebno zabrinjava konflikt između dve strane koje su doskora bile saveznici. Neka niko ne veruje da ima vremena da se izbegne spoljna vojna intervencija. Neka niko ne veruje da je vreme na njegovoj strani, da se može konsultovati do u beskraj i odugovlačiti pregovore [...] Koji god da je argument, dolazi vreme kada diskusija mora biti dovedena do kraja. Mi ćemo sada izneti ovaj spor Savetu bezbednosti, svetskom parlamentu, da bi se donela konačna odluka. Mi ćemo, kao kopredsednici, preporučiti Savetu bezbednosti da prihvati ovaj dogovor. Ako jedna ili više strana nastave da ga odbijaju, nadamo se da će Savet bezbednosti naći odgovarajuće mere da ga nametne, bile one političke, ekonomske ili vojne“ 72

Pitanje je, međutim, bilo da li su poluge ovog pritiska zaista u rukama pregovarača. „Kako sam obaviješten ta dvojica džentlmena imaju velike teškoće u Americi“, rekao je svojim saradnicima Izetbegović, ne krijući antipatiju prema Vensu i Ovenu: „Oni imaju velike teškoće u sazivanju sjednice Savjeta bezbednosti. Protive se tome, prije svega, Amerikanci““. ${ }^{73}$ I zaista, Klintonova administracija je sve otvorenije iskazivala rezerve spram Vens-Ovenovog plana. Odmah po inauguraciji Bila Klintona (20. januar 1993), novi savetnik za nacionalnu bezbednost Entoni Lejk pozvao je nadležne resore da na predsednikov zahtev do kraja meseca elaboriraju mogućnosti promene američke politike prema Bosni. Iako je ovaj predlog deklarativno podržavao mirovni proces, postavljao je i sledeće pitanje: „Ukoliko odredbe mirovnog sporazuma nisu u potpunosti zadovoljavajuće u principu ili u detaljima implementacije, mogu li ga SAD

\footnotetext{
${ }^{70}$ V. Petrović, Srpske političke elite i Vens-Ovenov plan I, 56-57.

${ }^{71}$ N. Koljević, $n$. d., 78-79.

${ }^{72}$ Zaključne napomene lorda Ovena pri zatvaranju plenarne sednice, u: B. Ramcharan, The International Conference on the Former Yugoslavia: Official Papers, II, 1223.

73 „Magnetofonski snimak sjednice Predsjedništva RBiH i predsjednika stranaka održane 2. februara 1993. godine“, u: T. Šimić, $n$. $d ., 16$.
} 
primenjivati tako da odu dalje od njegovih provizija, ili da deluju u pravcu ostvarivanja ciljeva koje sporazum ne obuhvata?“. ${ }^{74} \mathrm{U}$ tom cilju je osnovana radna grupa (DCI Balkan Interagency Task Force), čiji su predlozi uglavnom bili usmereni u pravcu većih pritisaka na srpsku stranu, dok je administracija stala na stanovište ,podrške posredovanju Ujedinjenih nacija i Evropske zajednice, ali ne neophodno i Vens-Ovenovog plana“".$^{75}$

Svestan kakav će utisak ova promena stavova imati na ionako nevoljne balkanske pregovarače, lord Oven je pisao britanskom ambasadoru u Vašingtonu da će mirovni predlog propasti ukoliko ne bude američkog ,pritiska na muslimansku stranu ako želi da nastavi da ratuje. Međutim, imamo Šaćirbeja koji otvoreno govori svima da američka administracija smatra da nema nikakvog razloga da se potpišu mape“. On je smatrao da je, ukoliko se takav stav promeni, sporazum i dalje nadohvat ruke, i nije krio svoje nezadovoljstvo: „Nisam se ja znojio pet meseci nad ovim mirovnim paketom da bih sada video da ga blokira američka administracija, posebno kada imamo sve signale da će sporazum podržati Evropska Zajednica i Ruska Federacija“" ${ }^{76}$ Sa svoje strane usmerio je pritisak na Slobodana Miloševića, u nadi da će srpsku stranu pridobiti za plan dok ne bude prekasno.

Ravno deceniju kasnije, ova dvojica ljudi srešće se u sudnici Haškog tribunala, gde je Dejvid Oven bio pozvan kao svedok u postupku protiv Slobodana Miloševića. Tokom njegovog svedočenja, tužilac se pitao da li je istinski verovao da bi Milošević odustao od prisajedinjavanja prekodrinskih Srba. Oven je izneo svoje viđenje: „On je bio pragmatičan. Samo on može da odgovori na to pitanje. Ja smatram da on to sigurno ne bi želeo da isključi dugoročno gledano. Međutim, nasuprot tome, ja mislim da je ponekad predsednik Milošević njima govorio da svet ide dalje. Ja u svom srcu smatram da je on, barem intelektualno gledano, shvatio da će Republika Srpska da ostane izvan Srbije. Ali zapravo ne znam“. U njihovu se debatu uključio i sam optuženi Milošević: „Pa vi ste sami rekli, lorde Oven, da smo proveli sate u argumentovanju razloga da se prihvate ti mirovni planovi. Da li vi smatrate da je trebalo da upotrebimo silu protiv Republike Srpske?“ Oven mu je odgovorio: „Pa ne mislim da je bilo neophodno da vi upotrebite silu, ja mislim da je ono što je trebalo da uradite jeste da prekinete dostavu goriva i da prekinete bilo šta drugo, osim obične humanitarne pomoći. [...] Tužilac: „Ja mislim da ste vi već rekli da je njegova

\footnotetext{
${ }^{74}$ Anthony Lake, Presidential Review Directrive NSC-1, US Policy Regarding the Situation in the Former Yugoslavia, January 22, 199322.1.1993, Central Intelligence Agency, Freedom of Information Act Electronic Reading Room, https://www.cia.gov/readingroom/docs/1993-0122.pdf (pristupljeno 20. 3. 2021).

75 Principals Committee Meeting on the Former Yugoslavia, 28 January 1993, Central Intelligence Agency, Freedom of Information Act Electronic Reading Room, https://www.cia.gov/readingroom/docs/1993-01-29.pdf_(pristupljeno 20. 3. 2021).

76 "Personal telegram from Lord Owen to UK Ambassador, Washington, sent by UK Mission, Geneva”, 29 January 1993, u: D. Owen, Bosnia-Herzegovina, 279. Više o razilaženju američke administracije i ženevskih pregovarača u: Bertrand Ramcharan, G. International Peace Conferences (Leiden: Brill, 2015), 192-193, 199-200.
} 
ambicija bila to da zadrži ličnu vlast i vi ste upotrebili analogiju, odnosno rekli ste 'da je on uzjahao tigra nacionalizma, i da je onda shvatio da je sa tog tigra teško sjahati, a da ga on ne ujede”“" Dejvid Oven: „Da, i na kraju ga je ujeo“. ${ }^{77}$ I ne samo njega, jer će i drugi protagonisti ove drame skončati u zatvoru, dok i one koji suda nisu videli ne mimoilazi sud istorije.

$$
* * *
$$

Ženevska etapa pregovora zaključena je 30. januara 1993, govorom Dejvida Ovena koji je ukazao na posledice neuspeha mirovnog procesa: „Odlaganjem se gubi više života, uništava se više imovine, i, što je najgore, umanjuju se šanse da tri naroda ponovo započnu suživot kao susedi““ ${ }^{78}$ Iskusni političar kao da nije shvatio da je najvećem broju njegovih sagovornika upravo to bio cilj. Oni nisu bili u stanju da prihvate mirovno rešenje bazirano na kompromisu, jer su čitavu svoju politiku gradili na fanatičnom srljanju u konflikt. Da bi u Ženevi priveli rat kraju, morali bi i sebi da objasne zašto su ga uopšte i vodili. Čak i da su psihološki bili spremni na taj korak, on je mogao štetiti njihovoj političkoj karijeri. Protiv njih bi se mogao okrenuti njihov elektorat i stranački aparat, kao i vojska i drugi instrumenti sile, a najbliži saradnici bi verovatno našli načina da se tom situacijom okoriste. Izetbegoviću je njegov prvi vojnik Sefer Halilović zamerao što samim sedenjem za istim stolom daje Karadžiću i Bobanu legitimitet, a bio je zaprepašten kada ga je video da se prijateljski pozdravlja sa Dobricom Ćosićem: „Taj tvoj prijatelj nam samo na Sarajevo skrka više od dva miliona granata“. ${ }^{79}$ Radovan Karadžić bi takođe morao da objasni napuštanje znatne teritorije pred Narodnom skupštinom Republike Srpske, u kojoj nije manjkalo poslanika koju su smatrali izdajom prepuštanje najmanjeg delića teritorije. ${ }^{80}$ Tako su protagonisti ženevske drame predstavljali ne samo gospodare, već i robove rata.

Otuda su se pregovori i odvijali u ritmu ,,jedan korak napred, dva koraka nazad". Međunarodni pregovarači su doduše uspeli da dobiju hrvatsku saglasnost. Dobili su čak i srpski pristanak na oba sporazuma, mada uslovljen skupštinskom ratifikacijom. Bosanska delegacija je odbila da potpiše vojni sporazum dok se ne definiše mehanizam razgraničavanja i kontrole teškog naoružanja, ali je dala podršku ustavnim principima. Prema tome, naoko je postignut određeni napredak, ali se ocrtao i nepremostiv problem - Sarajevo je zahtevalo da se

77 Svedočenje Dejvida Ovena 3-4. 11. 2003. Suđenje Slobodanu Miloševiću (Beograd: Fond za humanitarno pravo, 2006), tom 42, 407-514.

${ }^{78}$ Zaključne napomene lorda Ovena pri zatvaranju plenarne sednice, u: B. Ramcharan, The International Conference on the Former Yugoslavia: Official Papers, II, 1223.

${ }^{79}$ Sefer Halilović u gostovanju na FTV https://www.youtube.com/watch?v=9117u_7h1ow (pristupljeno 24. 1. 2021).

${ }^{80}$ Videti govore Radoslava Brđanina i Srđe Srdića na skupštinskoj sednici u: Thomas Dodd Center, Bosnian Serb Assembly Sessions, Session 24, 19-20.1.1993, 17-22, Robert J. Donia Collection, https://archives.lib.uconn.edu/islandora/object/20009\%3As25transcript\#page/1/ mode/2up (pristupljeno 24. 1. 2021). 
nakon obustave vatre što pre izvede povlačenje jedinica na nove linije razgraničenja, što je za Beograd bio neprihvatljiv redosled događaja. Čak je i hrvatska podrška planu bila više deklarativna nego suštinska, imajući u vidu rat koji se uveliko vodio u lašvanskoj dolini. Zapravo, obustava neprijateljstava u Bosni bi Zagrebu otežala budući obračun sa Republikom Srpskom Krajinom, a možda ga i onemogućila. Čak i da su druge dve strane svesrdno podržale sporazum, hrvatska strana bi verovatno našla načina da povuče svoju saglasnost. To je zapletu ženevske drame dalo karakteristike farse.

U njenoj osnovi je bilo ne samo nepoverenje, već i nespremnost aktera da prihvate svako mirovno rešenje koje je bilo suviše udaljeno od njihovih ratnih ciljeva. Različite pregovaračke taktike su samo prikrivale tu elementarnu činjenicu. Bosanska i srpska strana su se igrale igre ,ko prvi trepne“, nastojeći da jedna drugu okrive za prekid pregovora. Hrvatska strana je gradila imidž konstruktivnog partnera za pregovaračkim stolom, minirajući istovremeno mirovni proces eskalacijom sukoba na terenu. Ni međunarodna zajednica više nije stajala iza mirovnog plana jednoznačno, ostavljajući stranama u sukobu da $\mathrm{u}$ rascepu između Amerike, Rusije i Evrope traže svoju šansu. Tako su se ovi ljudi nadmudrivali, dok se rat nastavljao. Takav će obrazac preneti i na naredne pregovaračke etape - od modifikovanog Vens-Ovenovog i Oven-Stoltenbergovog plana do predloga Kontakt grupe pa sve do Dejtona. Da se u Ženevi njihova predstava u bilo kom od tri čina okončala drugačije, mnogi zločini bi bili izbegnuti, a živote bi sačuvala možda i čitava polovina od preko 100.000 žrtava ovog sukoba. To je raspletu ženevske drame dalo karakteristike tragedije. 


\section{REFERENCE}

- Beljo, Mijo. „Sukobi Armije Republike Bosne i Hercegovine i Hrvatskoga vijeća obrane u Gornjem Vakufu tijekom 1992. godine“. Časopis za suvremenu povijest, br. 2, (2016), 389-410.

- Bosna i Hercegovina u vreme raspada SFRJ 1990-1992: tematska zbirka dokumenata. Priredio Kosta Nikolić. Beograd: Institut za savremenu istori$\mathrm{ju} /$ Fond za humanitarno pravo, 2011.

- Bosnia-Herzegovina: The Vance/Owen Peace Plan. Ed. David Owen. Liverpool: Liverpool University Press, 2013.

- Caspersen, Nina. Contested Nationalism: Serb Elite Rivalry in Croatia and Bosnia in the 1990s. New York: Berghahn Books, 2009.

- Ćosić, Dobrica. Piščevi zapisi 1992-1993. Beograd: Filip Višnjić, 2004.

- Glaurdić, Josip. The Hour of Europe. Western Powers and the breakup of Yugoslavia. New Heaven: Yale University Press, 2011.

- Gow, James. Triumph of the Lack of Will. International Diplomacy and the Yugoslav War. London: Hurst\&co, 1997.

- Koljević, Nikola. Stvaranje Republike Srpske. Dnevnik 1993-1995. Beograd: Službeni glasnik, 2008.

- Milašinović, Arsen. "The Croat-Bosniak War: The Select Findings of the Recent Regional Historiography". Istorija 20. veka, br. 1. (2021), 197-214. https://doi.org/10.29362/ist20veka.2021.1.mil.197-214

- Nikolić, Kosta. „Srbija i plan lorda Karingtona na Mirovnoj konferenciji u Hagu 1991“. U: Jugoslavija između ujedinjenja i razlaza, Hrvatsko-srpski odnosi u kontekstu društvenog razvoja dve Jugoslavije 1918-1991. Uredili Bojan Dimitrijević i Mario Jareb, 225-260. Beograd: Institut za savremenu istoriju, 2018. https://doi.org/10.29362/2237.nik.225-260

- Owen, David. Balkan Odyssey. London: Indigo, 1996.

- Petrović, Vladimir. „Odnosi srpske političke elite i krah Vens-Ovenovog plana za BiH“. Istorija 20. veka, br. 1, (2012), 9-26. https://doi.org/10.29362/ ist20veka.2012.1.pet.9-26

- Petrović, Vladimir, priredio. Srpske političke elite $i$ Vens-Ovenov plan I-II. Beograd: Institut za savremenu istoriju, 2010, 2011.

- Petrović, Vladimir, priredio. Srpske političke elite i Londonska konferencija III. Beograd: Institut za savremenu istoriju, 2014, 2016.

- Plavšić, Biljana. Svedočim. Banja Luka: Trioprint, 2007.

- Ramcharan, Bertrand G. International Peace Conferences. Leiden: Brill, 2015. https://doi.org/10.1163/9789004245907

- Suđenje Slobodanu Miloševiću. Beograd: Fond za humanitarno pravo, 2006.

- Šimić, Tomo (prir). „Dokumenti Predsjedništva BiH 1991.-1994“. National Security and the Future, vol. 8, no. 2, (2007), 5-134.

- The International Conference on the Former Yugoslavia: Official Papers. Priredio Bertrand Ramcharan. Hague/Boston: Kluwer Law International, 1997. 
VLADIMIR PETROVIĆ, PhD, Principal Research Fellow

Institute for Contemporary History

Belgrade, Republic of Serbia

vladimir.petrovic@isi.co.rs

\author{
FAILURE OF GENEVA PEACE TALKS \\ TO END WAR IN BOSNIA IN JANUARY 1993
}

\title{
Summary
}

The International Conference on the Former Yugoslavia was created in London in August of 1992 as an instrument for the negotiations conducted by the United Nations and the European Community, represented by Cyrus Vance and Lord David Owen. Until the end of the year, they developed a detailed proposal to settle the Bosnian conflict, known as the Vance-Owen Peace Plan (VOPP). The VOPP was presented to the leaders of the warring factions in Geneva during the first session of talks in January of 1993. On the basis of archive material, judicial records, published documents, and memoirs of the participants, this article aims to reconstruct the dramatic negotiation process, which consisted of several rounds. An analysis of the declared Bosnian, Serbian, and Croatian positions during the negotiations, as well as the interactions among the delegations and relations within them, reveals that all the parties were had been deeply engaged in double dealing. The Croatian side was seemingly ready to sign the VOPP but was undermining it by launching a conflict in the field at the same time. The Serbian side was escalating as well, the Bosnian Serb leaders were not ready to accept the plan, despite the suggestions they had received from Belgrade. Sarajevo was procrastinating, hoping for a direct US involvement in the crisis following the inauguration of the new Clinton Administration. That administration did undermine the plan, which damaged the credibility of the international negotiators. In such circumstances, the plan had slim chances of succeeding. Although a ceasefire would have shortened the Bosnian war by almost three years and cut human losses by at least half, the main negotiators found a compromise solution to be unacceptable. As they defined and propagated maximalist goals, acceptance of a compromise was both damaging their grip on power and defying their worldview.

KEYWORDS: Bosnian War, International Conference on Former Yugoslavia, Slobodan Milošević, Radovan Karadžić, Franjo Tuđman, Alija Izetbegović, Vance-Owen Peace Plan 